\title{
Evaluating university-industry collaboration: the European Foundation of Quality Management excellence model-based evaluation of university- industry collaboration
}

\author{
Osmo Kauppila*, Anu Mursula, Janne Harkonen and Jaakko Kujala \\ Industrial Engineering and Management, University of Oulu, Oulu, Finland
}

\begin{abstract}
The growth in university-industry collaboration has resulted in an increasing demand for methods to evaluate it. This paper presents one way to evaluate an organization's collaborative activities based on the European Foundation of Quality Management excellence model. Success factors of collaboration are derived from literature and compared against the quality award criteria. Tailored evaluation criteria are proposed based on the analysis and piloted by evaluating a biosciences research umbrella organization. The results show that success factors of university-industry collaboration can be addressed by using the model-based evaluation criteria. The results of the study can potentially be used by actors on both sides of university-industry collaboration to evaluate their organization's collaboration capabilities and performance.
\end{abstract}

Keywords: university-industry; collaboration; evaluation; European Foundation of Quality Management excellence model

This is an Accepted Manuscript of an article published by Taylor \& Francis in Tertiary Education and Management on 12 Jun 2015, available online: https://doi.org/10.1080/13583883.2015.1045550.

\section{Introduction}

Collaborative activities between universities and industry have increased considerably during the last two decades. The reasons for this have been well studied and include motivations such as the advancement of technology, changes in the characteristics of industrial production and management practices, policies affecting universities and the availability of funding mechanisms (Chakrabarti \& Santoro, 2004; D'Este \& Patel, 2007; Grimaldi, Kenney, Siegel, \& Wright, 2011). Regardless of these developments, universityindustry collaboration still faces significant challenges (Bruneel, D'Este, \& Salter, 2010) and collaboration is often pursued in an ad hoc manner (Perkmann \& Salter, 2012).

As a result of increased interest, a large body of research has accumulated on this topic. This has focused on policy, technology and knowledge transfer, service productization, spin-offs, measurement and indicators and various stakeholder characteristics, as shown by extensive literature reviews covering the spectrum of current university-industry collaboration research topics (Perkmann et al., 2013; Teixeira \& Mota, 2012).

As Perkmann, Neely, and Walsh (2011) state: in order for university-industry alliances to be productive, they need to be properly structured and managed, and a key challenge is how to assess and evaluate them. Teixeira and Mota (2012) also identified measurement of collaboration as an emerging research topic. This study aims to contribute to the discussion by investigating the evaluation of university-industry collaboration. More particularly, the aim of this study is to investigate whether the collaborative activities of an organization could be evaluated using criteria based on the European Foundation of Quality Management (EFQM) excellence model, a holistic and non-prescriptive self-assessment model. The flexibility of the EFQM model could potentially allow its use in evaluation across different sectors, as the goals and working methods of collaboration depend on the organizational context.

The study has the following research questions:

(1) What factors affect the success of university-industry collaboration? 
(2) How can these factors be addressed in excellence model-based evaluation criteria?

The study follows the constructive research approach (Kasanen, Lukka, \& Siitonen, 1993) and its typical structure (Lindholm, 2008; Oyegoke, 2011). The aim of creating evaluation criteria for university-industry collaboration has both practical and research relevance. A literature review on the success factors of collaboration is performed to support the construction of the evaluation criteria. The research construct is formed by mapping the discovered success factors against the EFQM excellence criteria and adapting the criteria to more explicitly address these factors. The validity of the construct is tested through a pilot evaluation of the industry collaboration at Biocenter Oulu, a life sciences research organization at the University of Oulu, Finland.

\section{Literature review}

University-industry collaboration can take place in many forms, requiring different levels of formalization and organization (Thune, 2011). D'Este and Patel (2007) recognize five types: meetings and conferences, consultancy and contract research, creation of physical facilities, training and joint research. The drivers for universities to pursue collaboration include access to funding and technology, improved status in competing for public funding and feedback on practical validity of research, while for companies they include access to scientific competencies, ability to source innovation and ultimately to obtain competitive advantage as the result of collaboration (Bonaccorsi \& Piccaluga, 1994; Dooley \& Kirk, 2007; Perkmann \& Salter, 2012; Philbin, 2008).

In practice, building successful collaborative relationships has often proved challenging due to factors that can roughly be classified into two categories: a wide range of issues related to cultural differences between the organizations, and issues related to intellectual property and technology (Dooley \& Kirk, 2007; Perkmann \& Salter, 2012). The existing literature on collaboration can reveal some relevant success factors. Table 1 presents categorical factors affecting university-industry collaboration success.

Thinking strategically about the choice of partners, or 'assessing organizational fit' (Mead et al., 1999), can aid in developing productive university-industry relationships (Plewa \& Quester, 2007). Factors to consider include the strategic importance of the topic for both, complementary skills and expertise, evidence of recent corporate instability (Barnes, Pashby, \& Gibbons, 2002), geographical proximity (D'Este et al., 2012) and the size of the industry partners (Butcher \& Jeffrey, 2007). Both mutual and overall previous collaboration experiences affect success (Mora-Valentin, Montoro-Sanchez, \& GuerrasMartin, 2004). Previous collaboration experience lowers transaction-related 
Table 1. Factors affecting university-industry collaboration success.

Breadth of interaction: partners interact using multiple channels

Choice of partners: attention is paid to issues such as cultural fit, strategic fit and geographical proximity when planning partnerships

Clearly defined roles: roles and responsibilities are clearly defined and communicated

Clear policy on publication and intellectual property rights: policies and processes are transparent and agreed upon

Commitment to collaboration: senior management allocates appropriate resources for collaboration and acts in a champion role. Commitment in collaboration is accounted for in people management

Communication: channels for effective sharing of information exist and are actively used both within and between organizations

Working methods support value creation for both parties

Inter-organizational trust: mutual trust is a key requirement for success. The prerequisites for creating trust are in place

Mutually shared mission, goals and benefits: both parties understand and agree on the aims of collaboration

Previous collaboration experience: accumulating both mutual and overall collaborative experience increases the chance of success

Project management: collaboration projects are managed actively throughout their life cycle

Use of key performance indicators: collaboration is evaluated and monitored in a balanced way
Aapaoja, Kujala, and Pesonen (2012), Bruneel

et al. (2010), Butcher and Jeffrey (2007), D'Este and Patel (2007), Plewa and Quester (2007), Plewa et al. (2013), Rohrbeck and Arnold (2006)

Barnes et al. (2002), Barry and Fenton (2013), D'Este, Guy, and Iammarino (2012), Mead et al. (1999), Mora-Valentin et al. (2004), Plewa and Quester (2007), Thune (2011)

Barbolla and Corredera (2009), Barnes et al. (2002), Nielsen, Sort, and Bentsen (2013), Rohrbeck and Arnold (2006)

Barbolla and Corredera (2009), Bruneel et al. (2010), Bstieler, Hemmert, and Barczak (2015), Rohrbeck and Arnold (2006)

Barnes et al. (2002), Barry and Fenton (2013), Butcher and Jeffrey (2007), Mora-Valentin et al. (2004), Plewa and Quester (2007), Plewa et al. (2013), Rohrbeck and Arnold (2006), Schubert and Bjørn-Andersen (2012), Thune (2011)

Barnes et al. (2002), Barry and Fenton (2013), Butcher and Jeffrey (2007), Karlsson, Booth, and Odenrick (2007), Mead et al. (1999), Mora-Valentin et al. (2004), Plewa et al. (2013)

Barbolla and Corredera (2009), Barnes et al. (2002), Rohrbeck and Arnold (2006), Schubert and Bjørn-Andersen (2012)

Barbolla and Corredera (2009), Barnes et al. (2002), Bruneel et al. (2010), Bstieler et al. (2015), Nielsen et al. (2013), Plewa and Quester (2007), Plewa et al. (2013), Rohrbeck and Arnold (2006), Schubert and Bjørn-Andersen (2012)

Barnes et al. (2002), Butcher and Jeffrey (2007), Mead et al. (1999), Nielsen et al. (2013), Plewa et al. (2013), Rohrbeck and Arnold (2006)

Barnes et al. (2002), Bruneel et al. (2010), Butcher and Jeffrey (2007), Mora-Valentin et al. (2004)

Rohrbeck and Arnold (2006), Barnes et al. (2002), Butcher and Jeffrey (2007), Bstieler et al. (2015), Nielsen et al. (2013)

Barnes et al. (2002), Perkmann, Neely, and Walsh (2011), Plewa et al. (2013), Rohrbeck and Arnold (2006), Thune (2011) 
barriers (Bruneel et al., 2010), and supervisors having worked together before correlates with perceived success (Butcher \& Jeffrey, 2007).

The lack of clearly defined roles can result in a mismatch between expectations by both sides (Barnes et al., 2002) and adversely affect technology transfer (Barbolla \& Corredera, 2009). A possible division of roles can be the university staff working on research-oriented tasks, while the industry staff focuses on development activities (Rohrbeck \& Arnold, 2006). Having a clear and flexible policy on publication and intel- lectual property rights supports trust formation (Bstieler et al., 2015), as conflicts with technology-transfer organizations and university administration can potentially deter companies (Bruneel et al., 2010). Likewise, companies need to have the corporate capac- ity to utilize the results (Barbolla \& Corredera, 2009). The working methods should support value creation for both parties. The use of an appropriate set of research meth- ods promotes achieving both relevance and rigour (Schubert \& Bjørn-Andersen, 2012), and methods to support productization and even spinoffs may enable the researchers to focus on scientific work (Rohrbeck \& Arnold, 2006). The use of mature technology contributes to success in technology-transfer projects (Barbolla \& Corredera, 2009).

Active project management during the entire collaboration life cycle is important (Nielsen et al., 2013), and shared governance contributes to trust creation as well as enabling adjustments to changes in the project environment in a mutually agreed and coordinated manner (Bstieler et al., 2015). Managing conflicts in a clear and agreed-upon way also effects success (Mora-Valentin et al., 2004). The mission, goals and benefits for a collabora- tive relationship should be agreed at the very beginning of the collaboration, and be clearly communicated and managed throughout with the help of a suitable governance structure (Barnes et al., 2002; Mead et al., 1999). Deliverables should be clearly defined, describing how the different results build on each other (Rohrbeck \& Arnold, 2006).

Utilizing a broad range of interaction channels enhances research progress, promotes the formation of trust and contributes to collaboration success (Bruneel et al., 2010; D'Este \& Patel, 2007). While good personal relationships are beneficial, relying on them alone poses risks (Aapaoja et al., 2012; Rohrbeck \& Arnold, 2006). Communication can be supported by developing a clear communication strategy and structure, and by facilitating frequent interaction (Barnes et al., 2002; Mead et al., 1999), as especially inexperienced researchers may be hesitant to communicate with their supervisors and industry representatives (Butcher $\&$ Jeffrey, 2007). A part of effective communication is that higher education institutes should be able to market their capabilities (Barry \& Fenton, 2013).

Senior management commitment is particularly needed to overcome a natural resistance to risk taking and sharing of proprietary information (Barnes et al., 2002), and to motivate other participants (Bstieler et al., 2015). Commitment can also be influenced through human resources policy by employing researchers dedicated to collaborative research work (Rohrbeck \& Arnold, 2006), as well by rewarding success in collaboration (Barnes et al., 2002). The lack of academic incentives can deter academics from participating (Karlsson et al., 2007). Businesses interested in collaborating with universities need to understand that they need to commit to the relationship instead of expecting just-in-time quick fixes (Barry $\&$ Fenton, 2013). Inter-organizational trust is among the strongest success factors for collaboration (Bruneel et al., 2010), and the lack of it can result in not accepting the results generated by the partner (Rohrbeck \& Arnold, 2006). Trust can be built by starting out with smaller projects, building up trust and commitment over time (Barnes et al., 2002; Nielsen et al., 2013; Schubert \& Bjørn-Andersen, 2012; Thune, 2011). The role and behaviour of managerial champions (Bstieler et al., 2015) and project managers (Barnes et al., 2002) can strongly influence trust. 
The key performance indicators should be defined upon starting the operational phase of a collaboration project (Mead et al., 1999). They should account for various dimensions of success, and both 'softer' experiential metrics and 'harder' project success indicators should be used (Butcher \& Jeffrey, 2007; Perkmann, Neely, \& Walsh, 2011; Thune, 2011). The success indicators for each phase of a collaborative relation- ship can vary (Plewa et al., 2013).

The literature highlights a wide array of themes related to university-industry cooperation. The most prominent themes are related to organizational culture, aligning interests, and operating in a systematic and transparent manner.

\section{The EFQM quality award model}

The EFQM states that the excellence model is 'a comprehensive management framework used by over 30,000 organizations in Europe' (EFQM, 2012). It was first introduced in 1991 and has since been developed by the EFQM (Conti, 2007). The model is designed to be a frame of reference, enabling an organization to self-assess their performance according to determined criteria (Heras-Saizarbitoria, Casadesus, \& Marimon, 2011).

The model is based on the fundamental concepts of excellence identified by the EFQM. The concepts are linked to the evaluation criteria of the model. There are nine categories (Figure 1), which are further divided into sub-criteria (EFQM, 2012). They are based on the idea that results are derived from processes driven by the enablers (Nabitz \& Klazinga, 1999).

Besides industry, the EFQM criteria have been applied across numerous fields, including higher education (i.e. Davies, 2008; Hides, Davies, \& Jackson, 2004; Tari \& Madeleine, 2011), public administration (Cappelli, Guglielmetti, Mattia, Merli, \& Renzi,

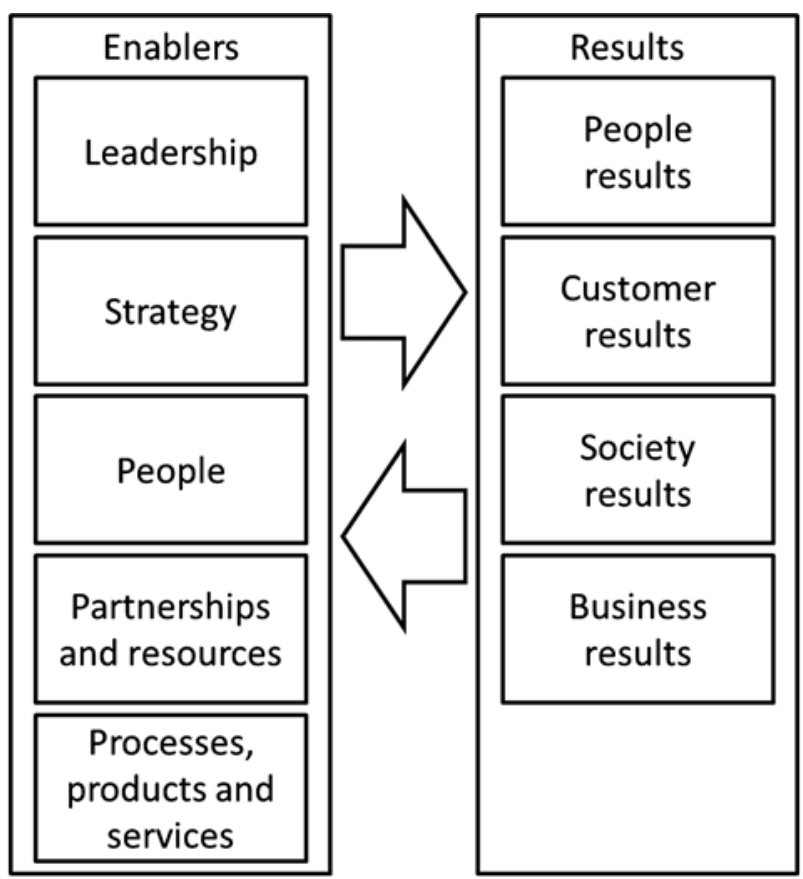

Figure 1. The EFQM excellence criteria. 
2011; George, Cooper, \& Douglas, 2003; Jacobs \& Suckling, 2007) and health care (Arcelay et al., 1999; Leigh, Douglas, Lee, \& Douglas, 2005; Vakani, Fatmi, \& Naqvi, 2011). The Malcolm Baldrige National Quality Award is the US equivalent of the EFQM. It is also available as an educational version and is widely adopted (Ruben, Russ, Smulowitz, \& Connaughton, 2007).

Since the EFQM model is non-prescriptive, it can be used for self-assessment in many ways (Wongrassamee, Simmons, \& Gardiner, 2003). The options vary from questionnaires and interviews to award applications and differ in rigour and in whether the results are based on opinion or evidence (Consortium for Excellence in Higher Education, 2003). In a higher education context, the limitations may include that the philosophy of the model (Figure 1) is too prescriptive, self-assessment is too resource and time consuming, and it requires prior knowledge and deliberate strategy for successful implementation and the subjectivity level of the assessment (Ernest Osseo-Asare \& Longbottom, 2002).

\section{Research construct for evaluating university-industry collaboration}

In order for the EFQM criteria to be suitable for evaluating university-industry collaboration, they need to account for the success factors that were identified in the literature review. Each of the success factors were classified within the categories of the criteria. These linkages between the success factors and the criteria are described in Table 2.

The EFQM evaluation criteria and sub-criteria were analysed and tailored to suit universityindustry collaboration based on the literature review and the comparison presented in Table 2. The resulting evaluation framework is presented in Table 3.

\section{The pilot evaluation}

The validity of the constructed evaluation framework was tested with an evaluation of industry collaboration at Biocenter Oulu (BCO). It is an umbrella organization responsible for building a research milieu for life sciences within the University of Oulu. The research projects in $\mathrm{BCO}$ are selected for four-year periods through an international evaluation on the basis of their research plans and scientific accomplishments. At the time of the evaluation, there were 10 research projects, 3 junior investigators and 6 coordinator projects. The topics range from studying the regulation of normal develop- ment to determining the molecular determinants in various pathological conditions such as metabolic syndrome, cancer or hypoxia-related diseases, and from the structure and functional properties of proteins to evolutionary genomics in plants. BCO employs roughly 270 people including project leaders, postdoctoral researchers, PhD students, technical staff and other support personnel.

The core facilities of BCO are a crucial part of the research milieu by offering adequate, often specialized equipment and demanding techniques crucial for modern life science research. The facilities are part of the Biocenter Finland Infrastructure networks and technology platform services and are integrated into the project groups. The core facilities serve academic and other customers in their research and development projects. The facilities have been evaluated to be on a good level by Biocenter Finland, which partially funds them (Biocenter Finland, 2013).

$\mathrm{BCO}$ was chosen as a target for pilot evaluation due to its research merits. For instance, in the 2013 research assessment exercise at the University of Oulu, four research communities including BCO research groups were ranked A for 'outstandingly strong research, also from an international perspective'. BCO was described as: 
doctoral education and an attractive setting to recruit gifted foreign scholars. [...] The strength of the RCs [research communities] that Biocenter Oulu embraces testifies to its value. (Eskelinen \& Ryyppö, 2014, p. 142) 
Table 2. Linkages between factors affecting collaboration success and the EFQM criteria.

\begin{tabular}{|c|c|c|c|c|c|}
\hline Leadership & Strategy & People & $\begin{array}{l}\text { Partnerships and } \\
\text { resources }\end{array}$ & $\begin{array}{l}\text { Processes, products and } \\
\text { services }\end{array}$ & Measures and indicators \\
\hline $\begin{array}{l}\text { Leaders recognize } \\
\text { collaboration in the } \\
\text { mission and vision of } \\
\text { the organization }\end{array}$ & $\begin{array}{l}\text { Collaboration is } \\
\text { included in the } \\
\text { organization's } \\
\text { strategy }\end{array}$ & $\begin{array}{l}\text { Collaboration roles and } \\
\text { responsibilities are } \\
\text { clearly defined }\end{array}$ & $\begin{array}{l}\text { Partnerships are } \\
\text { strategically planned }\end{array}$ & $\begin{array}{l}\text { The needs of partners are } \\
\text { identified and considered }\end{array}$ & $\begin{array}{l}\text { Collaboration } \\
\text { performance is measured, } \\
\text { evaluated and the results } \\
\text { are utilized }\end{array}$ \\
\hline $\begin{array}{l}\text { Leaders act as } \\
\text { champions of } \\
\text { university-industry } \\
\text { collaboration }\end{array}$ & $\begin{array}{l}\text { Creating value for } \\
\text { partners is accounted } \\
\text { for in strategy and } \\
\text { policy }\end{array}$ & $\begin{array}{l}\text { Capabilities required to } \\
\text { achieve mutual value } \\
\text { are recognized and } \\
\text { developed }\end{array}$ & $\begin{array}{l}\text { Aims of collaboration } \\
\text { are clearly agreed } \\
\text { upon with partners }\end{array}$ & $\begin{array}{l}\text { Collaboration processes } \\
\text { facilitate broad interaction } \\
\text { between partners }\end{array}$ & $\begin{array}{l}\text { Different dimensions of } \\
\text { collaboration success are } \\
\text { accounted for in the } \\
\text { indicators }\end{array}$ \\
\hline $\begin{array}{l}\text { Leaders interact with } \\
\text { collaboration } \\
\text { stakeholders }\end{array}$ & $\begin{array}{l}\text { Collaboration strategy } \\
\text { and policies are } \\
\text { communicated and } \\
\text { deployed }\end{array}$ & $\begin{array}{l}\text { People communicate } \\
\text { actively and } \\
\text { transparently } \\
\text { Success in collaboration } \\
\text { is recognized and } \\
\text { rewarded }\end{array}$ & $\begin{array}{l}\text { Clear processes and } \\
\text { policies for intellectual } \\
\text { property issues are in } \\
\text { place } \\
\text { Technology and } \\
\text { knowledge are kept } \\
\text { up-to-date }\end{array}$ & $\begin{array}{l}\text { Collaboration projects are } \\
\text { actively managed to } \\
\text { create an environment for } \\
\text { success } \\
\text { Capabilities, products and } \\
\text { services are } \\
\text { communicated and } \\
\text { marketed }\end{array}$ & \\
\hline
\end{tabular}


Table 3. EFQM excellence criteria adapted for evaluating university-industry collaboration.

(1) Leadership of university-industry collaboration

(a) Leaders recognize the importance of collaboration in the development of the mission and vision of the organization

(b) Leaders engage with customers, partners and representatives of society

(c) Leaders act as champions of university-industry collaboration

(2) Strategy of university-industry collaboration

(a) Collaboration is accounted for in the organization's strategy, accounting for the needs and expectations of the stakeholders

(b) Collaboration goals and strategy are based on understanding internal performance and capabilities

(c) Collaboration strategy and supporting policies are developed, reviewed and updated

(d) Collaboration strategy and supporting policies are communicated and deployed through plans, processes and objectives

(3) People involved in university-industry collaboration

(a) Roles and responsibilities are clearly defined to support the aims of collaboration

(b) People's knowledge and capabilities required to succeed in collaboration are recognized and developed

(c) People communicate effectively within their organization and throughout the collaborative partnership

(d) People are rewarded and recognized for success in collaboration

(4) Partnerships and resources of university-industry collaboration

(a) University-industry partnerships are managed, work on a mutually agreed basis and broad interaction in partnerships is supported

(b) Funding and financial resourcing for collaboration are managed to secure sustained success

(c) Technology is managed to support collaboration

(d) Information and knowledge, including intellectual property, are managed to support effective collaboration

(5) Processes, products and services of university-industry collaboration

(a) Processes, products and services are designed and managed to create value for both university and industry

(b) Collaboration projects are actively managed

(c) Products and services are effectively promoted and marketed

(6) Results of university-industry collaboration

(a) Performance indicators and goals for collaboration have been defined

(b) Different dimensions of success are accounted for in the indicators and goals

(c) Performance indicators and goals are actively managed and utilized 
Multiple methods were used for the collection of the evaluation data. The evaluator had indepth knowledge and experience of the organization, and worked as a project manager during the evaluation. Besides the evaluator's own expertise and the available material describing the organization, in-depth interviews with a key responsible person from the organization (I1) and a professional with extensive experience from innovations management, collaboration and the biosciences field (I2) were used to collect data. The interviews were structured around the evaluation criteria presented in Table 3 and transcribed.

\section{Collaboration leadership}

The mission and vision of Biocenter Oulu states three main functions for the organization: high-quality research, doctoral training and technology services. As an additional function BCO aims to support the local biotechnology field and innovation. The research groups are led by group leaders who decide upon the research content and the extent of industry collaboration:

Every research project leader is responsible for his project. You cannot really go and tell the group leaders how to do their job. After all, the leader has brought in the majority of funding and has been evaluated by an international panel to be on the highest level of international research among the evaluated university research groups. (II)

The scientific director can, however, influence the overall attitude towards collaboration via communicating the mission and vision to the group leaders. The amount of interest and activity varies a great deal between different research groups. In the earlier days in the field of bioscience, interaction with companies was seen as bad:

The leaders' eagerness to engage in industry collaboration really depends on their way of thinking ... It used to be that working with companies was an absolute no-no. Technical science areas first moved on from this mindset, bio- and other natural sciences are lagging a little in this. (I2)

Collaboration takes place in two forms, either through long-term relationships, or via the infrastructure core facilities that offer technology services. The core facilities have responsible coordinators, who often also lead their academic research groups. The technologies offered are always very tightly linked to the research focus area of the group. In both cases, leaders are deeply involved in the collaboration.

\section{Collaboration strategy}

The university has framed itself as an innovation university in its new strategy, so we are no longer just a multidisciplinary science university. Better start thinking more about those innovations. That's how industry contacts are inevitably born as well. (I2)

BCO's strategic focus on high-quality scientific research and doctoral education is complemented by industry collaboration. The relationships are long term and based on mutual trust and benefits, thus supporting the research unit's focus. Contract research is, however, seen to be too expensive for the area's biotech industry consisting of smaller businesses:

Being in an academic environment, our main tasks are research and education. But the third basic function is impact on society, and, well everybody aims for that. Of course, you want your research to have an impact. But you can't let short-term research be guiding research. For internationally high-level research, you need to work long term. (II) 
The technology services offered by the core facilities are open to all researchers and companies interested in using them. They improve the overall funding possibilities of BCO research groups by facilitating research work. Thus, the services and related competences are an important part of maintaining high-level know-how.

The infrastructure of these facilities is constantly improved by new equipment purchases. The motivation for the improvements is primarily academic, but the needs of the industry are also taken into consideration:

The presence of companies in the planning and steering groups of European Regional Development Fund projects is important, that's where you get feedback. In the best case we have common technological needs and by joining forces we can increase our chances to get funding and to jointly think about, for example, what are the funding sources for procuring equipment. (II)

Funding from national sources has so far covered the majority of the facilities' running costs, but due to the economic situation, an increasing amount of attention is paid to developing user fee systems for the facilities. The goal is that in the long run, user fees would cover the running costs of the facilities.

\section{People involved in collaboration}

The core facilities are headed by professors or group leaders, supported by scientists and technical staff taking care of the day-to-day activities. The staff are either dedicated to service tasks or involved in research projects. Balancing research and service work can be challenging, especially if service tasks appear during an intensive research period. The personnel of the core facilities are very experienced specialists and the services are linked to high-quality research. This ensures that the services are of high quality and technologically up-to-date:

It would be quite optimal to have some personnel that is not working on their 'own research' but are genuinely dedicated to service activities. Of course, the services still need to be linked to be connected to high-level research. But, for instance, there could be a professor responsible for the technology and its research use, but also some dedicated personnel for organizing these outbound service projects. (II)

Working as an expert in the core services is a career option for a researcher who does not wish to be a research group leader or a professor. It can even be seen as a safer career option and a chance to stay updated with the latest technologies.

\section{Partnerships and resources related to collaboration}

The foremost challenge for success in industry collaboration is funding ... Another challenge is related to understanding the needs of the companies, due to lack of experience in collaboration. (I2)

Managing the technological resources to support the strategy is the key idea in BCO core facilities, and the infrastructure of the facilities is constantly updated as well as the expertise of the staff. 
The users of the core facility currently only pay for the direct running costs of the facilities. There are, however, high pressures to charge indirect costs as well due to the need to increase outside funding. Nonetheless, increased prices could become an issue both for academic customers and for many start-up biotech companies:

Again, we arrive at the topic of demand. To be able to run a service you need to have enough customers to provide it, let's say cash flow, in order to hire a full-time researcher to run these service projects. Therein lies the challenge. (II)

How intellectual property rights and other contract issues are managed is still in the quite early stages of development. It has been only during recent years that researchers in the biotech field have started to protect their innovations. Earlier it was common to discuss openly about unpublished results. The reality has, however, shown that it is wise to protect the knowledge:

Non-disclosure policies are something not everyone is used to. For instance, it can be unclear what a non-disclosure agreement means - what are you allowed to discuss without breaching the agreement and so on. (I2)

In $\mathrm{BCO}$, there are no dedicated personnel to take care of intellectual property rights issues, but help is sought from the university innovations services. For instance, the effect of patenting on research is sometimes unclear:

Many think that patenting slows down dissertation and publication work. It is not really the case, patenting takes a few months so it is not like you have to wait for years before you can publish anything. (I2)

\section{Collaboration products, processes and services}

Collaboration processes and productization of the services are at different developmental stages depending on the core facility. Each of the nine core facilities has developed their services depending on the nature of their service so the processes are not unified. It was felt that clearer pricing guidelines on a university level would help in allocating the costs of the services:

Pricing services and defining processes are not always simple. In some instances, such as generating transgenic mice, the process is clear and repeatable, and the resources and costs incurred can be clearly defined. On the other hand, there are more complex cases such as protein crystallography. Each protein behaves as an individual and one cannot know how easily it crystallizes and whether the crystals produce usable data. The generation of a service concept is just in its infancy, and maybe the projects could be divided into smaller partial projects and after each one the continuation could be re-evaluated, and the terms negotiated. (II)

It has become evident that for scientists in the fields of bioscience and medicine marketing their knowhow is difficult. Also, communicating the expertise available in terms that everyone can understand is challenging and scientists tend to make advertising the ser- vices too complicated. A European Regional Development Fund project is currently trying to tackle these problem areas and trying to make the local biotech companies more aware of the available services: 
Describing and advertising our core services in this kind of popularized way and using 'catchy words' is something we have a lot of work ahead. Projects or theses maybe ... It would be good to have someone with an outsider view doing this ... For a researcher this kind of activities are difficult, it would be better to have a business-oriented marketing person working on this. (II)

In some universities, services offered by the university have been separated from research by setting up a separate company to offer the services. In BCO, this could, however, jeopardize the most important role of the core facilities as facilitators of research.

\section{Discussion}

EFQM excellence model-based criteria for evaluating university-industry collaboration was found to be useful for $\mathrm{BCO}$ in its goals to evaluate and continuously improve its industry cooperation. In the evaluation of $\mathrm{BCO}$, the most relevant improvement area was found to be processes, products and services. However, it was also observed that this section is strongly influenced by other areas, such as leadership, strategy and people; what is the strategy for collaboration, how leaders implement this strategy and communicate it to people and finally, how leaders and other staff together transform the expertise into products, services and processes.

In comparison, Kleyn, Kitney, and Atun (2007) studied research and development collaboration in the UK life science sector, and found the main challenges to be funding problems of university research teams, pricing, intellectual property ownership disagreements, differences in capabilities regarding partnering, and problems related to administrative support and excessive bureaucracy. In addition to productization and processes, all these issues were discussed in the BCO pilot evaluation as well.

The motivation and ways to engage with industry are somewhat field-specific, as noted by Perkmann, King, and Pavelin (2011). As the success factors derived from the literature are quite generic and the EFQM criteria are non-prescriptive, it can be argued that the evaluation framework combining these should be applicable across various disciplines. However, this inevitably means that the presented evaluation criteria are not an instant solution. Understanding of model-based self-assessment and knowledge of the target organization are required for application. This is in accordance with the limitations of EFQM in higher education self-assessment as pointed out by Ernest Osseo-Asare and Longbottom (2002).

Even though a university organization was studied in this research, there seems to be no reason why the presented criteria could not be applied to the industry side of collaboration as well, as they are based on general success factors. As Perkmann and Salter (2012) point out, firms need to recognize and address challenges related to university collaboration in order to be desirable partners for academia and for the collaboration to succeed.

A key issue is whether the structure of the EFQM criteria is the best one for this evaluation task. The criteria and sub-criteria structure can be argued to be too prescriptive (Ernest Osseo-Asare \& Longbottom, 2002). One should also not forget that quality award models are based on total quality management and its principles. Their applicability towards higher education has been debated from various angles, including a cultural mismatch of assumptions (Jauch \& Orwig, 1997), ignoring key academic processes (Koch, 2003) and that total quality management promotes conformity while higher education should promote diversity (Houston, 2007). 
The rigour of EFQM excellence model-based evaluation can be adjusted according to the organization's needs so it supports different levels of collaborative maturity. Adding more detailed statements to support the sub-criteria could further refine the evaluation criteria and make them more useful to organizations with more mature collaboration processes. At the same time, it could result in a more rigid approach and the result would be daunting for less mature organizations.

Evaluation using quality management-based models highlights the use of systematic approaches. However, it could be argued that in an academic context, informal approaches are more suitable. For example, the finding that research collaboration is often based on personal relationships (Aapaoja et al., 2012) can also be construed as good practice and not a risk source. Also, the case results show that in a highly performing research organization collaboration can be at least partially informal. Still, the evaluation model presented in the study is not prescriptive, and as such does not condemn or exclude the use of informal practices.

Due to the research-oriented focus of the existing literature and the nature of the case organization, the results are focused on research activities, while education and learning do not explicitly show in the results. While this does not discredit the use of the presented evaluation criteria in an education-focused organization, it does require evaluator expertise for interpreting them in an educational context.

\section{Conclusion}

Collaboration between universities and industry has drastically increased recently. The drivers and success factors for this have been thoroughly analysed. A less-studied, yet important, topic is how to measure and evaluate this collaboration and its success. This article analyses the potential of basing the evaluation of university-industry collaboration on the EFQM excellence model.

The success of collaboration is influenced by various factors that are discussed in the research literature. This study combines and categorizes those factors. The success factors comprise various themes aiming to bridge the cultural differences between academia and industry and to create an environment of trust and commitment, in which collaboration can take place in an organized manner while aiming towards mutually agreed goals.

The identified success factors were mapped against the EFQM model, and the comparison in Table 2 shows the links between the recognized success factors and the EFQM evaluation criteria. Evaluation criteria for collaboration (Table 3) were proposed as the outcome of the comparison. The validity of the criteria was tested by evaluating the industry collaboration of BCO, an umbrella organization for life sciences research within the University of Oulu. The pilot evaluation was successful and proved to be of help in pinpointing the relevant areas needing improvement in the organization's cooperation with industry.

The results of the study suggest that EFQM excellence model-based evaluation of university-industry collaboration encompasses the success factors derived from the literature, and that it is a viable option for evaluating and developing the collaboration activities of an organization. Due to its non-descriptive nature, an excellence model could be applicable across various disciplines and for both parties involved in university-industry collaboration. As the maturity level of collaboration varies greatly between organizations, the rigour of evaluation should be adjusted accordingly. 
In this study, the proposed evaluation criteria were piloted in a research umbrella organization. Further evaluation use would shed more light on the positive and negative aspects of assessing collaboration with excellence model-based evaluation criteria. Possible topics for further research include testing the presented criteria in more depth and elaborating a more detailed evaluation framework to aid organizations with more mature collaboration processes. Another potentially fruitful topic would be the evaluation of individual collaborative relationships while accounting for the current phase of the collaboration life cycle of the particular linkage.

\section{References}

Aapaoja, A., Kujala, J., \& Pesonen, L. T. T. (2012). Productization of university services. International Journal of Synergy and Research, 1, 89-106.

Arcelay, A., Sánchez, E., Hernández, L., Inclán, G., Bacigalupe, M., Letona, J., ... MartínezConde, A. E. (1999). Self-assessment of all the health centres of a public health ser- vice through the European Model of Total Quality Management. International Journal of Health Care Quality Assurance, 12, 54-59.

Barbolla, A. M. B., \& Corredera, J. R. C. (2009). Critical factors for success in university-industry research projects. Technology Analysis \& Strategic Management, 21, 599-616.

Barnes, T., Pashby, I., \& Gibbons, A. (2002). Effective university-industry interaction: A multi- case evaluation of collaborative R\&D projects. European Management Journal, 20, 272-285.

Barry, A. M., \& Fenton, M. (2013). University-industry links in R\&D and consultancy in Ireland's indigenous high-tech sector. Irish Geography, 46, 51-77.

Biocenter Finland. (2013). Biocenter Finland technology platform user survey 2013. Retrieved from http://www.biocenter.fi/images/documents/FINAL-BF-User-survey-report.pdf

Bonaccorsi, S., \& Piccaluga, A. (1994). A theoretical framework for the evaluation of universityindustry relationships. $R \& D$ Management, 24, 229-247.

Bruneel, J., D'Este, P., \& Salter, A. (2010). Investigating the factors that diminish the barriers to university-industry collaboration. Research Policy, 39, 858-868.

Bstieler, L., Hemmert, M., \& Barczak, G. (2015). Trust formation in university-industry collaborations in the US biotechnology industry: IP policies, shared governance, and champions. Journal of Product Innovation Management, 32, 111-121.

Butcher, J., \& Jeffrey, P. (2007). A view from the coal face: UK research student perceptions of successful and unsuccessful collaborative projects. Research Policy, 36, 1239-1250.

Cappelli, L., Guglielmetti, R., Mattia, G., Merli, R., \& Renzi, M. F. (2011). Peer evaluation to develop benchmarking in the public sector. Benchmarking: An International Journal, 18, 490-509.

Chakrabarti, A. K., \& Santoro, M. D. (2004). Building social capital and learning environment in university-industry relationships. International Journal of Learning and Intellectual Capital, 1 , $19-36$.

Consortium for Excellence in Higher Education. (2003). Applying self-assessment against the EFQM Excellence Model in further and higher education. Sheffield: Sheffield Hallam University.

Conti, T. (2007). A history and review of the European Quality Award Model. The TQM Magazine, $19,112-128$.

Davies, J. (2008). Integration: Is it the key to effective implementation of the EFQM Excellence Model? International Journal of Quality and Reliability Management, 25, 383-399.

D'Este, P., Guy, F., \& Iammarino, S. (2012). Shaping the formation of university-industry research collaborations: What type of proximity does really matter? Journal of Economic Geography, 13, $537-558$. 
D'Este, P., \& Patel, P. (2007). University-industry linkages in the UK: What are the factors underlying the variety of interactions with industry? Research Policy, 36, 1295-1313.

Dooley, L., \& Kirk, D. (2007). University-industry collaboration: Grafting the entrepreneurial paradigm onto academic structures. European Journal of Innovation Management, 10, 316-332.

EFQM (European Foundation of Quality Management). (2012). An overview of the EFQM Excellence Model. Brussels: Author.

Ernest Osseo-Asare, A., \& Longbottom, D. (2002). The need for education and training in the use of the EFQM model for quality management in UK higher education institutions. Quality Assurance in Education, 10, 26-36.

Eskelinen, S., \& Ryyppö, A. (Eds.). (2014). Research assessment report 2014. International evaluation of research at the University of Oulu. Oulu: Juvenes. Retrieved from http://www. oulu.fi/external/RAE2013/OuluUniv_RAE2014_report.pdf

George, C., Cooper, F., \& Douglas, A. (2003). Implementing the EFQM excellence model in a local authority. Managerial Auditing Journal, 18, 122-127.

Grimaldi, R., Kenney, M., Siegel, D. S., \& Wright, M. (2011). 30 years after Bayh-Dole: Reassessing academic entrepreneurship. Research Policy, 40, 1045-1057.

Heras-Saizarbitoria, I., Casadesus, M., \& Marimon, F. (2011). The impact of ISO 9001 standard and the EFQM model: The view of the assessors. Total Quality Management \& Business Excellence, $22,197-218$.

Hides, M., Davies, J., \& Jackson, S. (2004). Implementation of EFQM excellence model selfassessment in the UK higher education sector - Lessons learned from other sectors. The TQM Magazine, 16, 194-201.

Houston, D. (2007). TQM and higher education: A critical systems perspective on fitness for purpose. Quality in Higher Education, 13, 3-17.

Jacobs, B., \& Suckling, S. (2007). Assessing customer focus using the EFQM excellence model: A local government case. The TQM Magazine, 19, 368-378.

Jauch, L. R., \& Orwig, R. A. (1997). A violation of assumptions: Why TQM won't work in the ivory tower. Journal of Quality Management, 2, 279-292.

Karlsson, J., Booth, S., \& Odenrick, P. (2007). Academics' strategies and obstacles in achieving collaboration between universities and SMEs. Tertiary Education and Management, 13, 187201.

Kasanen, E., Lukka, K., \& Siitonen, A. (1993). The constructive approach in management accounting research. Journal of Management Accounting Research, 5, 243-264.

Kleyn, D., Kitney, R., \& Atun, R. A. (2007). Partnership and innovation in the life sciences. International Journal of Innovation Management, 11, 323-347.

Koch, J. V. (2003). TQM: Why is its impact in higher education so small? The TQM Magazine, 15, $325-333$.

Leigh, J. A., Douglas, C. H., Lee, K., \& Douglas, M. R. (2005). A case study of a preceptorship programme in an acute NHS Trust - Using the European Foundation for Quality Management tool to support clinical practice development. Journal of Nursing Management, 13, 508-518.

Lindholm, A.-L. (2008). A constructive study on creating core business relevant CREM strategy and performance measures. Facilities, 26, 343-358.

Mead, N., Beckman, K., Lawrence, J., O’Mary, G., Parish, C., Unpingco, P., \& Walker, H. (1999). Industry/university collaborations: Different perspectives heighten mutual opportuni- ties. Journal of Systems and Software, 49, 155-162.

Mora-Valentin, E. M., Montoro-Sanchez, A., \& Guerras-Martin, L. A. (2004). Determining factors in the success of R\&D cooperative agreements between firms and research organizations. Research Policy, 33, 17-40.

Nabitz, U. W., \& Klazinga, N. S. (1999). EFQM approach and the Dutch quality award. International Journal of Health Care Quality Assurance, 12, 65-71.

Nielsen, C., Sort, J. C., \& Bentsen, M. J. (2013). Levers of management in university-industry collaborations: How project management affects value creation at different life-cycle stages of a collaboration. Tertiary Education and Management, 19, 246-266.

Oyegoke, A. (2011). The constructive research approach in project management research. International Journal of Managing Projects in Business, 4, 573-595.

Perkmann, M., King, Z., \& Pavelin, S. (2011). Engaging excellence? Effects of faculty quality on university engagement with industry. Research Policy, 40, 539-552. 
Perkmann, M., Neely, A., \& Walsh, K. (2011). How should firms evaluate success in universityindustry alliances? A performance measurement system. $R \& D$ Management, 41, 202-215.

Perkmann, M., \& Salter, A. (2012). How to create productive partnerships with universities. MIT Sloan Management Review, 53, 79-105.

Perkmann, M., Tartari, V., McKelvey, M., Autio, E., Broström, A., D’Este, P., ... Sobrero, M. (2013). Academic engagement and commercialisation: A review of the literature on universityindustry relations. Research Policy, 42, 423-442.

Philbin, S. (2008). Process model for university-industry research collaboration. European Journal of Innovation Management, 11, 488-521.

Plewa, C., Korff, N., Johnson, C., Macpherson, G., Baaken, T., \& Rampersad, G. C. (2013). The evolution of university-industry linkages - A framework. Journal of Engineering and Technology Management, 30, 21-44.

Plewa, C., \& Quester, P. (2007). Key drivers of university-industry relationships: The role of organisational compatibility and personal experience. Journal of Services Marketing, 21, 370382.

Rohrbeck, R., \& Arnold, H. M. (2006). Making university-industry collaboration work - A case study on the Deutsche Telekom Laboratories contrasted with findings in literature. In ISPIM 2006 conference: 'Networks for Innovation' (pp. 1-11). Athens, Greece. Retrieved from http://mpra.ub.uni-muenchen.de/5470/1/MPRA_paper_5470.pdf

Ruben, B. D., Russ, T., Smulowitz, S. M., \& Connaughton, S. L. (2007). Evaluating the impact of organizational self-assessment in higher education. Leadership \& Organization Development Journal, 28, 230-250.

Schubert, P., \& Bjørn-Andersen, N. (2012). University-industry collaboration in IS research: An investigation of successful collaboration models. In Proceedings of the International Bled Conference 2012 (pp. 109-126). Bled, Slovenia.

Tari, J. J., \& Madeleine, C. (2011). Preparing Jordanian university services to implement a quality self-assessment methodology. International Review of Administrative Sciences, 77, 138-158.

Teixeira, A. A. C., \& Mota, L. (2012). A bibliometric portrait of the evolution, scientific roots and influence of the literature on university-industry links. Scientometrics, 93, 719-743.

Thune, T. (2011). Success factors in higher education-industry collaboration: A case study of collaboration in the engineering field. Tertiary Education and Management, 17, 31-50.

Vakani, F., Fatmi, Z., \& Naqvi, K. (2011). Three-level quality assessment of a dental hospital using EFQM. International Journal of Health Care Quality Assurance, 24, 582-591.

Wongrassamee, S., Simmons, J. E. L., \& Gardiner, P. D. (2003). Performance measurement tools: The balanced scorecard and the EFQM excellence model. Measuring Business Excellence, 7, 14 29. 